\title{
DO We REALLY NEED THE ANNS TEST FOR DUTY OF CARE IN NEGLIGENCE?
}

\author{
JoOST BLOM ${ }^{*}$
}

\begin{abstract}
Since its formal adoption in 1984, the Supreme Court of Canada has applied the Anns test 31 times. This article uses those decisions to assess the test's value in negligence law. Based on that analysis, the Anns test has two disadvantages: (1) it treats dissimilar duty questions as if they were alike; and (2) it can divert courts into an Anns analysis when a more direct approach to duty of care would be better. However, despite its disadvantages, three decades of continued use by the Supreme Court makes it unlikely that the Anns test will be abandoned anytime soon.
\end{abstract}

\section{TABLE OF CONTENTS}

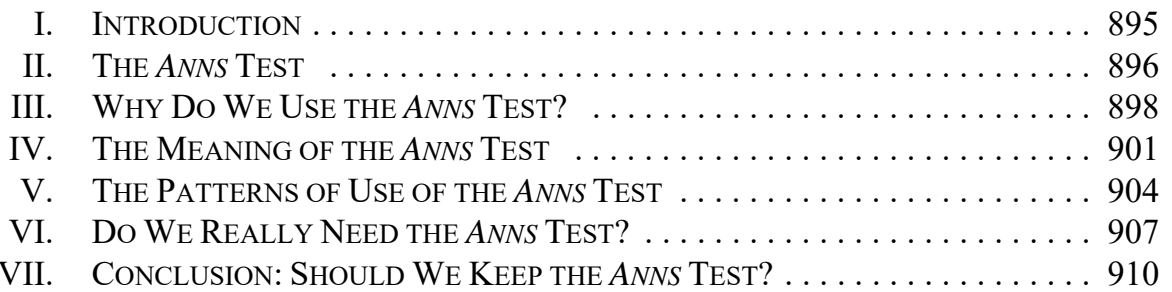

\section{INTRODUCTION}

The Supreme Court of Canada's attachment to the Anns test for determining questions of duty of care in tort is a remarkable example of judicial loyalty. The Court has maintained its belief in Anns despite the test being not only superseded, but actually denounced, by the court that originated it. Since it formally adopted the test in 1984 the Court has applied it 31 times in a wide range of cases. ${ }^{1}$

Professor, Peter A Allard School of Law, University of British Columbia. The author is grateful to Cammy Hui and Lisa Wang, both currently second year JD students at the Allard School of Law, who undertook on their own initiative to do some unpaid research for this article. It is a privilege to contribute to an issue of this Alberta Law Review in honour of Lewis Klar. He has been a valued and inspiring colleague, not only as a tort scholar, but also as a university administrator when, for some years, we were law school Deans at the same time. My choice of topic for this article was prompted in part by Lewis Klar's having written on it in "Foreseeability, Proximity and Policy" (2002) 25:3 Adv Q 360.

Kamloops v Nielsen, [1984] 2 SCR 2 [Kamloops]; BDC Ltd v Hofstrand Farms Ltd, [1986] 1 SCR 228 [Hofstrand]; Laurentide Motels Ltd v Beauport (City), [1989] 1 SCR 705 [Laurentide]; Just v British Columbia, [1989] 2 SCR 1228 [Just]; Rothfield v Manolakos, [1989]2 SCR 1259 [Rothfield], Canadian National Railway Co v Norsk Pacific Steamship Co, [1992] 1 SCR 1021 [Norsk]; Brown v British Columbia (Minister of Transportation and Highways), [1994] 1 SCR 420 [Brown]; Swinamer v Nova Scotia (Attorney General), [1994] 1 SCR 445 [Swinamer]; Galaske v O'Donnell, [1994] 1 SCR 670 [Galaske]; Winnipeg Condominium Corporation No 36 v Bird Construction Co, [1995] 1 SCR 85 [Winnipeg Condo]; Stewart v Pettie, [1995] 1 SCR 131 [Stewart]; D’Amato v Badger, [1996] 2 SCR 1071 [D'Amato]; Hercules Managements Ltd v Ernst \& Young, [1997] 2 SCR 165 [Hercules]; Lewis (Guardian ad litem of) v British Columbia, [1997] 3 SCR 1145 [Lewis]; Bow Valley Husky (Bermuda) Ltd v Saint John Shipbuilding Ltd, [1997] 3 SCR 1210 [Bow Valley]; Dobson (Litigation Guardian of) $v$ Dobson, [1999] 2 SCR 753 [Dobson]; Ingles v Tutkaluk Construction Ltd, 2000 SCC 12, [2000] 1 SCR 298 [Ingles]; Martel Building Ltd v Canada, 2000 SCC 60, [2000] 2 SCR 860 [Martel]; Cooper v Hobart, 2001 SCC 79, [2001] 3 SCR 537 [Cooper]; Edwards v Law Society of Upper Canada, 2001 SCC 80, [2001] 3 SCR 562 [Edwards]; Odhavji Estate v Woodhouse, 2003 SCC 69, [2003] 3 SCR 263 [Odhavji]; Young v Bella, 2006 SCC 3, [2006] 1 SCR 108 [Young]; Childs v Desormeaux, 2006 SCC 18, [2006] 1 SCR 643 [Childs]; Syl Apps Secure Treatment Centre v BD, 2007 SCC 38, [2007] 3 SCR 83 [Syl Apps]; Hill v Hamilton-Wentworth Regional Police Services Board, 2007 SCC 41, [2007] 3 SCR 129 [Hill]; Design Services Ltd v Canada, 2008 SCC 22, [2008] 1 SCR 737 [Design Services]; Holland 
This article uses these 31 decisions as the basis for assessing how valuable a part of our law of negligence the Anns test has proved to be. The mass of lower court decisions applying the test are largely left unexplored, partly for reasons of practicality and partly because they would not help much in answering this question. The Supreme Court's decisions have charted the sometimes twisting path for the test and provided the leading precedents in practically all the types of case to which the test has so far been applied. ${ }^{2}$

\section{The AnNS TeST}

As everyone familiar with English or Canadian tort law knows, the Anns test originated in 1978 as a response to the pressure to adapt negligence law to new types of defendant (mainly public authorities or others exercising statutory authority), new types of damage (mainly pure economic loss), and new types of duty (mainly duties to take positive steps to protect the interests of another). Anns v. Merton London Borough Council itself involved all three. ${ }^{3}$ The claim was for pure economic loss suffered by the owners (on long leases) of flats in a building. The foundations had allegedly been negligently inspected, or not inspected at all, by the local authority so that the flats suffered structural damage. ${ }^{4}$ The question of duty of care was argued as a preliminary question.

The House of Lords held the local authority was under a duty of care. In the leading speech, Lord Wilberforce framed a general approach that English courts should henceforth use in deciding duty questions in new situations:

First one has to ask whether, as between the alleged wrongdoer and the person who has suffered damage there is a sufficient relationship of proximity or neighbourhood such that, in the reasonable contemplation of the former, carelessness on his part may be likely to cause damage to the latter — in which case a prima facie duty of care arises. Secondly, if the first question is answered affirmatively, it is necessary to consider whether there are any considerations which ought to negative, or to reduce or limit the scope of the duty or the class of person to whom it is owed or the damages to which a breach of it may give rise. ${ }^{5}$

v Saskatchewan, 2008 SCC 42, [2008] 2 SCR 551 [Holland]; Fullowka v Pinkerton's of Canada Ltd, 2010 SCC 5, [2010] 1 SCR 132 [Fullowka]; Reference re Broome v Prince Edward Island, 2010 SCC 11, [2010] 1 SCR 360 [Broome]; Alberta v Elder Advocates of Alberta Society, 2011 SCC 24, [2011] 2 SCR 261 [Elder Advocates], R v Imperial Tobacco Canada Ltd, 2011 SCC 42, [2011] 3 SCR 45 [Imperial Tobacco]. This article has not counted London Drugs Ltd v Kuehne \& Nagel International Ltd, [1992] 3 SCR 299, because only Justice La Forest used it to support his conclusion that the employees handling the transformer owed no duty of care at all, whereas the majority thought there was a duty, but liability was almost entirely excluded by contract. Lower courts have since applied the Anns test to deny that an employee who damages an employer's property is under any duty of care to the employer: Douglas v Kinger (Litigation Guardian of), 2008 ONCA 452, 90 OR (3d) 721; Portage La Prairie Mutual Insurance Co v MacLean, 2012 NSSC 341, 321 NSR (2d) 269. This article has not counted Hall $v$ Hebert, [1993] 2 SCR 159, in which the majority did not rely on Anns to define the ambit of the ex turpi defence, nor has it not counted Ryan v Victoria (City), [1999] 1 SCR 201, because Anns was ultimately held inapplicable to the issue in the case, which was standard of care rather than duty. Anns was also cited in one pre-Kamloops decision, Barratt $v$ The Corporation of the District of North Vancouver, [1980] 2 SCR 418, on the policy-operational distinction.

Compare a study like Andrew Robertson, "Policy-based reasoning in duty of care cases" (2013) 33:1 LS 119 [Robertson, "Policy"], which looks at a database of UK and Canadian duty of care decisions (57 in Canada in one year alone) to analyze statistically how various policy considerations play out in the courts' decisions at all three levels.

(1977), [1978] AC 728 (HL (Eng)) [Anns].

The loss was purely economic because no person or property was injured by the alleged negligence. The loss was simply that the flats had to be repaired, or resold for less than they would otherwise have been worth.

Anns, supra note 3 at 751-52. 
The Supreme Court of Canada adopted the two-stage approach in Kamloops, ${ }^{6}$ also an action by a house buyer against a municipality for economic loss caused by defective foundations. ${ }^{7}$ The Court held, as Anns had done, that a duty of care was established. Justice Wilson restated the test as follows:

(1) is there a sufficiently close relationship between the parties ... so that, in the reasonable contemplation of [one person], carelessness on its part might cause damage to [the other] person? If so,

(2) are there any considerations which ought to negative or limit (a) the scope of the duty and (b) the class of persons to whom it is owed or (c) the damages to which a breach of it may give rise? ${ }^{8}$

The changes in the "slightly modified version"9 adopted in Kamloops are essentially editorial. ${ }^{10}$ Even the truncation of the reference in the first limb of the test, from Lord Wilberforce's "sufficiently close relationship of proximity or neighbourhood" to Justice Wilson's "sufficiently close relationship," has proved to be insignificant given the Court's subsequent emphasis on the significance of "proximity."

In England, the Anns test had a short life. In 1990, after Anns had been subject to heavy criticism both in and outside the courts, the House of Lords "departed from" (that is, overruled) it in Murphy v. Brentwood District Council. ${ }^{11}$ It too was a claim in negligence against a local authority for the economic loss to a building owner caused by defective construction. The House of Lords could have decided against that duty of care without also denouncing the Wilberforce approach to novel duties of care generally. It is clear, however, that the judges in Murphy saw the wrong conclusion on the particular duty question as directly attributable to a wrong approach, as reflected in the Wilberforce formula, to duties of care in general. ${ }^{12}$

The Wilberforce two-stage test therefore sank from view in England. The only general structure the English courts have since adopted to determine whether a duty of care exists in a novel situation is to ask, not only whether damage to the plaintiff was a foreseeable result of the defendant's negligence, but also whether it is "fair, just and reasonable" to impose liability for that damage on the defendant. ${ }^{13}$ Australia never did accept the Wilberforce formula. It adheres to an incremental methodology ${ }^{14}$ that is keyed to the "salient features"

Kamloops, supra note 1.

The actual negligence of the city related not to the inspection itself but to what it should have done to follow up on the defects that were disclosed by the inspection.

Kamloops, supra note 1 at 10-11.

Winnipeg Condo, supra note 1 at 113.

Although the Supreme Court has referred to the test as the "Anns/Kamloops" test, which may suggest that the modification in Kamloops was significant (see, for instance, Cooper, supra note 1 at para 14; Broome, supra note 1 at para 13), for simplicity's sake, the Canadian test will be referred to in this article as the Anns test.

(1990), [1991] 1 AC 398 (HL (Eng)) at 399 [Murphy].

Ibid at 461, where Lord Keith said he preferred the "incremental approach" of Justice Brennan in The Council of the Shire of Sutherland v Heyman, [1985] HCA 41, 157 CLR 424 [Sutherland], to the twostage Anns test. All the other judges agreed with Lord Keith though some gave supplemental reasons. Caparo Industries plc v Dickman, [1990] 2 AC 605 (HL (Eng)); see also Michael v Chief Constable of South Wales Police, [2015] UKSC 2, [2015] AC 1732.

Sutherland, supra note 12 at para 14 of Justice Brennan's judgment. 
of the circumstances of the type of case being considered. ${ }^{15}$ New Zealand has followed Anns to the extent of adopting an approach that looks both at proximity and wider policy considerations. ${ }^{16}$ But not in an explicit two-stage test: "the ultimate judgment must be one that is "fair, just and reasonable.",17

In the following sections, this article will examine what reasons support the retention of the Anns test, how the test has been used over the last thirty years, and whether, on the whole, the test adds value to Canadian tort law.

\section{Why Do We USE The ANNS TeST?}

Given the strength of the Supreme Court of Canada's attachment to Anns, it is surprising how little the Court has said to explain that attachment, even when faced with the courts' abandonment of Anns in its country of origin. In Kamloops, which was the decisive first embrace of Anns, the Court simply saw itself as "[f]ollowing the path charted by Lord Wilberforce."18 The Court's discussion of the merits of Anns is more negative than positive, as it is basically confined to refuting criticisms of the Anns approach in the specific context of the liability of bodies acting under statutory authority. ${ }^{19}$

When the Supreme Court decided Norsk ${ }^{20}$ in 1992, the House of Lords had repudiated Anns. ${ }^{21}$ The Court was, of course, asked by defendant's counsel to follow the House of Lords in doing so. The Court, both majority and dissenting judges, declined. They equated Anns with preserving flexibility in the area particularly of duties of care with respect to pure economic loss. This was better than the "insistence on logical precision" that the court saw as the essence of the House of Lords' position. ${ }^{22}$ Justice McLachlin (as she was then) said that a comparative review of the law on pure economic loss

suggests that the incremental approach to the problem of determining the limits for the recovery of pure economic loss which was adopted by this Court in Kamloops should be confirmed. Where new categories of claim arise, the court should consider the matter first from the doctrinal point of view of duty and

Perre v Apand Pty Ltd, [1999] HCA 36, 198 CLR 180 at para 198; Woolcock Street Investments Pty Ltd $\checkmark$ CDG Pty Ltd, [2004] HCA 16, 216 CLR 515 at paras 74, 164 (but see Justice Kirby at para 159, suggesting the guidance offered by the salient principles approach is "less than clear"); Brookfield Multiplex Ltdv Owners Corporation Strata Plan 61288, [2014] HCA 36, 254 CLR 185 at paras 30, 115. See also Carolyn Sappideen \& Prue Vines, eds, Fleming's The Law of Torts, 10th ed (Sydney, Austl: Lawbook, 2011) at 154; Prue Vines, "The Needle in the Haystack: Principle in the Duty of Care in Negligence" (2000) 23:2 UNSWLJ 35.

16 Rolls-Royce New Zealand Ltd v Carter Holt Harvey Ltd, [2004] NZCA 97, [2005] 1 NZLR 324.

17 Couch v Attorney General, [2008] NZSC 45, [2008] 3 NZLR 725 at para 52, Elias CJ. See also Justice Tipping's suggestion that the question was still open as to whether proving proximity gives rise to any presumption of a duty of care (at para 79). In North Shore City Council v Attorney-General, [2012] NZSC 49, [2012] 3 NZLR 341 at para 152, Justice Blanchard said that the New Zealand approach and the Canadian approach to duty of care were essentially similar. The relatively unstructured approach taken by the New Zealand courts is supported by: Toni Moyes, "Handle With Care': Labels and Content of the Duty of Care in Negligence" (2005) 11:1 Canterbury L Rev 1.

18 Kamloops, supra note 1 at 11.

19 See ibid at 25, where Justice Wilson answers the "floodgates" argument by noting that the test has "built-in barriers against the flood." These barriers were the need for the empowering statute to impose a private law duty of care, and the exclusion of liability for purely policy decisions made in the bona fide exercise of discretion.

$20 \quad$ Norsk, supra note 1.

21 Murphy, supra note 11; Kamloops was noted but disagreed with at 473-74. Norsk, supra note 1 at 1149. 
proximity, as well as the pragmatic perspective of the purposes served and the dangers associated with the extension sought. $^{23}$

It is striking that Justice McLachlin chose "incremental approach" to describe the Canadian position, based on Anns, when that was the very expression that the House of Lords in Murphy had used to describe what Anns was not. ${ }^{24}$ What enabled her to do so was the addition to the Anns approach of a new, or newly explicit, threshold requirement. The duty question must arise in the context of "new categories of claim."

This idea had far-reaching implications because it not only defined when Anns is to be used, but also implied an important qualification as to how it is to be used. Inherent in the "new categories" criterion is the notion that, whenever Anns is applied, the newly recognized - or rejected - duty must be couched in terms of a "category" of claims. It is this that allowed Justice McLachlin to use the label "incremental approach" to describe what Anns is meant to do, thus presumably allaying worries, which the House of Lords clearly felt, that the two-stage approach in Anns would tend to operate as an undisciplined, duty-creating machine. On a proper view of Anns, new categories of duty would be added only when precedent allowed it, and incrementally each time for a defined category of claim.

In this respect, Justice McLachlin's approach echoed Justice La Forest's in Norsk. He dissented from her conclusion that the defendant tug owed a duty of care to the plaintiff railway as the main user of the damaged bridge. He referred to the five categories of cases that tort liability had so far been imposed for pure economic loss. ${ }^{25}$ These were (1) the independent liability of statutory public authorities; (2) negligent misrepresentation; (3) negligent performance of a service; (4) negligent supply of shoddy goods or structures; and (5) relational economic loss. The claim in Norsk was of the fifth type. He favoured a rule that no duty of care exists for such loss except for "reasonably well defined and circumscribed" exceptions dealing with joint ventures, general average contributions, and the plaintiff having a possessory or proprietary interest in the damaged asset. ${ }^{26}$

In the Bow Valley case five years later, Justice McLachlin noted that, in Norsk, she and Justice La Forest (who also sat on Bow Valley) agreed that "relational economic loss is recoverable only in special circumstances where the appropriate conditions are met [and that] these circumstances can be defined by reference to categories, which will make the law generally predictable. ${ }^{, 27}$ Thus, the three subcategories within the relational economic loss category where a duty of care does exist were confirmed as: "(1) cases where the claimant has a possessory or proprietary interest in the damaged property; (2) general average cases; and (3) cases where the relationship between the claimant and property owner constitutes a joint venture." 28

Ibid at 1150 .

Murphy, supra note 11 at 461.

Norsk, supra note 1 at 1049, citing Bruce Feldthusen, "Economic Loss in the Supreme Court of Canada: Yesterday and Tomorrow" (1991) 17:3 Can Bus LJ 356 at 357-58.

Norsk, ibid at 1131. The third of these is not really an exception because, if the plaintiff has such an interest in the damaged property, the loss is not pure economic loss but consequential economic loss. Bow Valley, supra note 1 at para 48.

Ibid. 
After Norsk, the Court's next reflection on the role of the Anns test was in the very type of case in which the House of Lords had been moved to discard it. The claim was for the economic loss associated with acquiring a building with a latent defect. In Winnipeg Condominium the Court below had followed the English cases denying that the owner of a building could claim for such loss against those who had negligently constructed the building. ${ }^{29}$ In giving the judgment reversing the decision, Justice La Forest, like the House of Lords in Murphy, essentially identified the merits of the two-part test with the merits of the liability rule. The House of Lords was wrong to reject liability for dangerous construction defects and, by the same token, it was wrong to reject the two-part test. He said:

[I]n respect of both the appropriate test with regard to the recoverability of economic loss and the recoverability of the cost for repairing dangerous defects, this Court has chosen not to take the path followed by the House of Lords in D \& F Estates and Murphy. In the first place, this Court has not followed the House of Lords in repudiating the two-part test established by Lord Wilberforce in Anns. ${ }^{30}$

The Court's most recent discussion of why the Anns test is part of our law came in Cooper. There the question was whether a provincial government owed a duty of care to investors who lost money because the government negligently failed to use its regulatory powers to shut down an unsound mortgage broker in a timely fashion. The Court substantially altered the Anns test in deciding that no duty of care was owed. This alteration will be discussed below. The Court emphasized, however, that the test had a secure place in the Canadian law of torts:

This Court has repeatedly affirmed that approach [the Anns test] as appropriate in the Canadian context.

The importance of Anns lies in its recognition that policy considerations play an important role in determining proximity in new situations. Long before Anns, courts in Canada and elsewhere had recognized that the decision of how far to extend liability in negligence involved policy considerations.

Anns did not purport to depart from the negligence test of Donoghue v. Stevenson but merely sought to elucidate it by explicitly recognizing its policy component. ${ }^{31}$

Thus, as far as the general purpose of the Anns test is concerned, the Supreme Court has said little more than that it offers a more flexible and nuanced solution to solving duty issues (said in the context of pure economic loss cases), and that the test explicitly recognizes the importance of policy in deciding questions of duty of care (said in Cooper, a public authority case). It has linked the test to a category-by-category approach. The next part of this article discusses how the Court has actually used the test, as a basis for assessing whether the test actually adds value to Canadian law.

Winnipeg Condo, supra note 1.

Ibid at 113. The "second place" was the Court's own dicta favouring Justice Laskin's dissenting view in Rivtow Marine Ltd $v$ Washington Iron Works, [1974] SCR 1189, that the owner of a chattel should be able to sue the designer and manufacturer of it for pure economic loss associated with repairing a dangerous defect in the chattel: Winnipeg Condo, ibid at 114.

Cooper, supra note 1 at paras 24-25, 27. 


\section{The Meaning of the AnNs Test}

The meaning of the Anns test has varied over the thirty or so years that it has been in use, even if the verbal formula has stayed the same. The Supreme Court has been punctilious about repeating the Anns test verbatim, either in the original or as reworded by Justice Wilson in Kamloops. ${ }^{32}$ However, a watershed in the Court's use of the Anns test came in Cooper. ${ }^{33}$

It had always been unclear as to whether the first limb of the test (Lord Wilberforce's "relationship of proximity or neighbourhood") involved factors other than whether the defendant could foresee harm to the plaintiff. The Court had had two occasions prior to Cooper to say that the answer was: yes, other factors were involved. The first was in Norsk. ${ }^{34}$ Both Justice McLachlin, in the majority, and Justice La Forest, in dissent, centred their analysis of the tug's duty of care on the first limb of the Anns test.

Justice McLachlin emphasized that it was not just a foreseeability test, but more generally a proximity test. In relational economic loss claims, a test of foreseeability alone would produce almost infinite arrays of duties of care; if an asset is damaged it is always foreseeable that the damage may have economic consequences for people other than the owner of the asset. A damaged bridge was a textbook example. Hence Justice McLachlin's recourse to proximity as the way to sort out which claims should succeed and which should not. She had to admit that "[p]roximity may be usefully viewed, not so much as a test in itself, but as a broad concept which is capable of subsuming different categories of cases involving different factors." 35 She described the content of proximity mainly in factual terms. It "may consist of various forms of closeness - physical, circumstantial, causal or assumed - which serve to identify the categories of cases in which liability lies." 36 Based on the railway's use of the bridge, the location of the bridge as a link in its main line, and its role in maintaining the bridge, proximity was found to exist. This proximate relationship was located in the "joint" or "common venture" category, which operated as an exception to the general position that no duty of care existed to those suffering relational economic loss. ${ }^{37}$

Justice La Forest favoured a broad rule denying a duty of care in relational economic loss cases, and differed from Justice McLachlin on the usefulness of proximity as part of the first limb in this context. Proximity, he said, "is incapable of providing a principled basis for drawing the line on the issue of liability" 38 as it "has practically no predictive value." 39

The second opportunity was in Hercules, a negligent misstatement case. Here it was Justice La Forest, in his judgment for the Court, who seized on proximity as a necessary part of the first limb. The difference was that this was a case, not on relational economic loss, but on negligent misrepresentation. Determining whether a prima facie duty of care exists in a

Kamloops, supra note 1.

Cooper, supra note 1 .

Norsk, supra note 1.

Ibid at 1151 .

Ibid at 1152 .

Ibid at 1162 .

Ibid at 1114 .

Ibid at 1130 . 
particular case "consists in an attempt to discern whether, as a matter of simple justice, the defendant may be said to have had an obligation to be mindful of the plaintiff's interests in going about his or her business. ${ }^{40}$ It was the job of proximity to distinguish cases where the defendant had such a responsibility from cases where he or she did not. ${ }^{41}$ In negligent misrepresentation claims, the two elements that established proximity were the foreseeability of harm to the defendant, and the reasonableness of the plaintiff's reliance on what the defendant said. ${ }^{42}$

Justice La Forest felt it necessary to explain that looking at the second element "is not, as might first appear, to abandon the basic tenets underlying the first branch of the Anns/Kamloops formula." 43 The first limb was concerned with whether "a duty of care would be imposed by law," as distinct from whether it "ought to be negatived or ousted by policy considerations," ${ }^{44}$ which was the task of the second limb. In his view, both foreseeability of loss and reasonableness of reliance went to the first question, not the second.

In Cooper the court greatly enlarged the ambit of the proximity inquiry. ${ }^{45}$ In both Norsk and Hercules it had tried to maintain a distinction between proximity and policy, as if the first and second limbs of the Anns test reflected questions that were different in kind; proximity being the key to the first and policy to the second. Thus, in Hercules, the Court said that the defendant's knowledge of the plaintiff, and whether the plaintiff used the statements for the particular transaction for which they were provided, was "in reality, nothing more than a means by which to circumscribe - for reasons of policy - the scope of a representor's potentially infinite liability." 46 Consequently, such considerations were to be brought in at the second, or "policy branch of the Anns/Kamloops test.",47

This distinction was bound to break down because the kind of evaluation process being conducted under the rubric of proximity clearly had policy underpinnings. This was now openly acknowledged in Cooper. Chief Justice McLachin and Justice Major, who spoke for the Court, said, "[t]he importance of Anns lies in its recognition that policy considerations play an important role in determining proximity in new situations." 48 Anticipating the objection that injecting policy considerations into the first limb of the test muddied, if not erased, the distinction between the first and second limbs, they went on: "[w]e continue in the view, repeatedly expressed by this Court, that the Anns two-stage test, properly understood, does not involve duplication because different types of policy considerations are involved at the two stages." 49

Ibid.

Ibid at para 25

Ibid.

The significance of that expansion for the pure economic loss cases is discussed in Russell Brown, "Still Crazy After All These Years: Anns, Cooper v Hobart and Pure Economic Loss" (2003) 36:2 UBC L Rev 159. The merits of the Court's methodology are discussed by Lewis Klar, "Foreseeability, Proximity and Policy" (2002) 25:3 Adv Q 360.

Hercules, supra note 1 at para 28.

Ibid at para 30 .

Cooper, supra note 1 at para 25.

Ibid at para 28 . 
What, then, is the difference between the two sets of policy considerations? The answer was:

[T] he Anns analysis is best understood as follows. At the first stage of the Anns test, two questions arise: (1) was the harm that occurred the reasonably foreseeable consequence of the defendant's act? and (2) are there reasons, notwithstanding the proximity between the parties established in the first part of this test, that tort liability should not be recognized here? The proximity analysis involved at the first stage of the Anns test focuses on factors arising from the relationship between the plaintiff and the defendant. These factors include questions of policy, in the broad sense of that word. If foreseeability and proximity are established at the first stage, a prima facie duty of care arises. At the second stage of the Anns test, the question still remains whether there are residual policy considerations outside the relationship of the parties that may negative the imposition of a duty of care. ${ }^{50}$

In the abstract, it is hard to draw a clear line between policy factors having to do with the relationship between the parties, and those that are residual and outside the relationship. The duty question starts with the nature (or category) of the claim. That is defined by the relationship between the parties. Given that the relationship defines the nature of the claim, it does not make much sense to talk about policies for and against imposing a duty of care as being outside the relationship. However, the distinction made practical sense in the context of the Cooper case. In any action against someone exercising statutory authority, the relationship is defined by the statute. What the court's bifurcation of policy considerations enabled it to do is distinguish between policy reasons having to do with the defendant's statutory role, as part of the relationship, and those extrinsic to that role. ${ }^{51}$

The Court did not spell out why the former were better handled at the first stage than at the second. ${ }^{52}$ The key must lie in the notion of a prima facie duty of care, and the question when it is - or is not - right to recognize that such a prima facie duty exists (even if for policy reasons liability is denied). If the compatibility of the defendant's statutory duties with a private law duty of care comes in only at the second stage, practically every statutory body would be subject to a prima facie duty of care in carrying out any of its responsibilities. By definition, such a body's exercise of its powers has a foreseeable impact on the physical or financial welfare of those affected by its action.

How best to frame decisions on public authority liability involves a question of optics. For a court to find in a particular case that there is a prima facie duty of care, but then to deny liability on policy grounds, has the appearance of choosing to withhold an entitlement from the plaintiff. This appearance is especially strong in cases of citizens who are claiming that a public authority did not live up to its obligation to look after their interests. It is simply more palatable, to both the courts and citizen-plaintiffs, to turn back the citizens' claims by saying that the authority was not even under a prima facie duty of care. The alternative is to

Card at para 30 [emphasis in original]

Cases after Cooper, supra note 1 restated its significance, but in slightly varying terms, discussion of which is omitted here. See Bruce Feldthusen \& Allen M Linden, Canadian Tort Law, 10th ed (Toronto: LexisNexis, 2015) (the Court has now "clarified its clarification of Anns" at 320).

52 Some commentators have seen the greater policy freight loaded onto the first, or prima facie duty, part of the test as more or less aligning Canadian law with the English "fair, just and reasonable" approach: Lewis N Klar, Tort Law, 5th ed (Toronto, Ont: Carswell, 2012) at 179; Philip H Osborne, The Law of Torts, 4th ed (Toronto, Ont: Irwin Law, 2011) at 70-71. 
say, "Well, there was a prima facie duty, so there was a kind of wrong done to you, but we are going to absolve the defendant authority of liability for policy reasons."

\section{The Patterns of Use of the AnNs Test}

Turning from the meaning of the Anns test to its application in practice, to what kinds of duty issues has the Supreme Court applied the test since it was adopted in Kamloops? The first point to observe is that the link between the test and novel categories of claim is more complicated than it might seem at first sight. The notion of categories of claim means quite different things in different types of claim.

As already noted, the Supreme Court has applied the Anns test 31 times since (and including) Kamloops. Eighteen involved claims against public authorities or other entities exercising functions regulated by statute. ${ }^{53}$ Thirteen cases (including one that is doublecounted because it also involved a public authority defendant) involved novel duties of care being asserted against private individuals or entities. In nine of these the issue was the nature of the damage; all were claims for pure economic loss. ${ }^{54}$ In the other four the problem was the nature of the asserted duty, because the claims were essentially for nonfeasance. The defendant was said to have been under an obligation to take positive steps to prevent the plaintiff from being injured or killed in an accident caused by a third party. ${ }^{55}$

Kamloops, supra note 1 (municipal building bylaw enforcement - duty and breach found policy/operational); Rothfield, supra note 1 (municipal building permit - duty and breach found); Laurentide, supra note 1 (municipal fire protection measures - duty and breach found - Quebec law); Just, supra note 1 (provincial highway maintenance - duty found); Brown, supra note 1 (provincial highway maintenance - duty found but no breach or causation); Swinamer, supra note 1 (provincial highway maintenance - duty found but no breach); Lewis, supra note 1 (provincial highway maintenance - duty and breach found); Ingles, supra note 1 (municipal building inspection - duty and breach found); Cooper, supra note 1 (provincial regulation of mortgage brokers - no duty); Edwards, supra note 1 (law society's regulation of legal profession - no duty); Odhavji, supra note 1 (municipal police chief and police board responsibility for police behaviour - arguable duty on one but not the other); Syl Apps, supra note 1 (treatment centre involved in plaintiff's daughter being made ward of the Crown - no duty); Hill, supra note 1 (regional police responsibility for investigation of plaintiff - duty found but no breach); Holland, supra note 1 (province misclassifying plaintiff's game farms - no duty except arguable with respect to implementing court order); Fullowka, supra note 1 (province's responsibility to protect miners' safety — duty found but no breach); Broome, supra note 1 (province and trustee's responsibility for abuse at a children's home - no duty); Elder Advocates, supra note 1 (province's responsibility for regulation of nursing home finances - no duty); Imperial Tobacco, supra note 1 (federal government's responsibility for promoting light cigarettes - no duty).

Hofstrand, supra note 1 (economic loss from delayed delivery of package — no duty); Norsk, supra note 1 (economic loss to users from interruption of service of a third party's bridge - duty and breach found); Winnipeg Condo, supra note 1 (economic loss to building owner from latent, dangerous defect — duty found); D’Amato, supra note 1 (relational economic loss - no duty); Hercules, supra note 1 (economic loss from negligent misrepresentation - no duty); Bow Valley, supra note 1 (relational economic loss - no duty); Martel, supra note 1 (economic loss from negligent failure to negotiate renewal of lease - no duty); Young, supra note 1 (economic impact on plaintiff of university official's negligent reporting to authorities that plaintiff might be a child abuser - duty and breach found); Design Services, supra note 1 (economic loss to subcontractor from awarding project to non-compliant bidder - no duty).

55 Galaske, supra note 1 (driver's duty to take positive steps to ensure that the minor plaintiff wears a seat belt - duty found, breach to be determined); Stewart, supra note 1 (bar's duty to take positive steps to prevent the plaintiffs' driver from driving away in car after drinking too much — duty found but no breach or causation); Childs, supra note 1 (social host's duty to injured member of the public to take positive steps to prevent a guest from driving after drinking too much — no duty); Fullowka, supra note 1 (private security firm's duty to take positive steps to protect miners' safety - duty found but no breach). 
Thus, all but one of the Supreme Court's cases fell into either of two broad types: (1) public authority cases; and (2) private actor liability for new types of harm (usually pure economic loss) or new types of obligation (usually duties of affirmative action). The one case that falls outside these two areas was Dobson, a case involving, not a novel duty of care, but a novel reason for denying a duty of care. The reason was that the plaintiff was claiming for injuries he suffered as a result of his mother's negligence before he was born. ${ }^{56}$

It is noteworthy that the category aspect of the Anns test is different, depending on the nature of the issue. ${ }^{57}$ Where the issue is the liability of public or quasi-public entities exercising statutory functions, each new statutory regime is a new category. For each new function, the Anns test must be carried out in full. ${ }^{58}$ Here, the proximity part of the first limb analysis is crucial, as Cooper demonstrates, because that is where a judge considers whether imposing a private law duty of care would adversely affect the defendant's ability to carry out its statutory responsibilities. In many cases the other important issue is whether the act or omission should be characterized as the exercise of a right to decide policy as distinct from the operational carrying out of that policy. This is considered, according to Cooper, ${ }^{59}$ at the second, residual policy consideration stage of the test. ${ }^{60}$

Where the issue is private actor liability for a new form of damage or a new form of obligation, the category approach fits better. Cases are typed according to the factual pattern they present. If the factual pattern is not relevantly different from ones in which a duty has been found, there is no need to apply Anns. The best example of the category approach working well is Childs, the social host case. Here the Court undertook an extensive analysis of whether the commercial host cases, which held that a duty of care did exist, formed a broad category into which social hosts fell as well. The Court held that social hosts should be treated as a separate category of liability because they were differently placed, in relevant respects, from commercial hosts. ${ }^{61}$

There is one use of Anns in relation to private actor liability that raises particular problems in this respect. The Court in Hercules took the view that negligent misstatement was not one category of duty, but an infinite range of subcategories for which the Anns test must be applied. That was because, in the Court's view, it is the second limb of Anns that is best suited to evaluating whether, despite the foreseeability and reasonableness of the plaintiff's reliance (which are the first-stage elements), a duty of care should not be imposed because it would result in indeterminate liability (as in Hercules itself), or for some other reason. ${ }^{62}$

Dobson, supra note 1

The difficulties with the "category" aspect of the Anns test are explored by Klar, supra note 52 at 183-85.

58 See Bergen v Guliker, 2015 BCCA 283, [2015] 11 WWR 258. The issue was whether police were under a duty of care, before a stolen car pursuit commenced, to not even start the pursuit. It was held to be a new category, and the judge erred by carrying out a partial Anns analysis. This "category" was not so much a new statutory function as a new factual situation within that function. Cooper, supra note 1 at para 53.

The most complete consideration so far of this particular residual consideration is found in Imperial Tobacco, supra note 1 . See Bruce Feldthusen, "Public Authority Immunity from Negligence Liability: Uncertain, Unnecessary, and Unjustified” (2014) 92:2 Can Bar Rev 211.

61 Childs, supra note 1 at paras 16-23.

62 Hercules, supra note 1. 
The current status of Hercules is debatable. It is pre-Cooper, and the considerations that the Court treated as second stage in Hercules - notably whether the defendant had knowledge of the precise purpose for which the plaintiff would use the information or advice - could now be seen as part of the proximity analysis at the first stage.$^{63} \mathrm{It}$ is also arguable that Hercules' idea that Anns should be applied in this area, so as to better integrate the handling of duty in negligent misstatement cases with the handling of duty in other forms of negligence, has turned out not to be viable. ${ }^{64}$ In fact, given the Court's current view of the Anns test, Hercules actually does treat negligent misstatement differently because it uses Anns as a determinant for a duty of care in individual cases, not categories of cases. ${ }^{65}$ It can be added that, in practice, the lower courts have not taken Hercules' embrace of Anns to heart. Many lower courts dealing with negligent misstatement claims have seen no real difference between applying Anns, as Hercules said they should, and applying the special relationship criterion. Many have simply continued to use the latter despite Hercules having said that it ought to be superseded. ${ }^{66}$

The most notable duty problem to which the Supreme Court has not yet had the opportunity to apply Anns to is psychiatric injury. ${ }^{67} \mathrm{Here}$, as with negligent misstatement, it is very difficult to do what the courts have done with pure economic loss and duties of affirmative action, namely, use the Anns test to generate defined subcategories in which a duty will or will not exist. Aside from broad distinctions, like whether the victim was him or herself at physical risk or just a bystander to the accident, each psychiatric injury case is a category unto itself in which, assuming foreseeability is met, the other elements of proximity - however they may be defined in this context - have to be assessed from scratch. $^{68}$

Generally speaking, all the relevant features of the plaintiff's position, including its ability to manage in advance the risk of the defendant's negligence, seem to be proximity rather than residual issues. Such countervailing concerns are discussed in Jane Stapleton, "Duty of Care: Peripheral Parties and Alternative Opportunities for Deterrence" (1995) 111:2 Law Q Rev 301.

${ }_{64}$ See Hercules, supra note 1 at para 21: "[T] c create a 'pocket' of negligent misrepresentation cases ... in which the existence of a duty of care is determined differently from other negligence cases would ... be incorrect." The "pocket" reference is to Jane Stapleton, "Duty of Care and Economic Loss: A Wider Agenda" (1991) 107:2 Law Q Rev 249.

65 It could be argued that this is an overstatement and Hercules, ibid, should be seen as deciding on a duty of care in a category, namely, auditors' liability. If so, however, the category is not wide. The Court's application of the second stage policy considerations was not geared to auditors' opinions generally, but to a particular kind of auditors' report prepared for a particular kind of purpose.

66 This is so, especially because in its earlier decision in Queen $v$ Cognos Inc, [1993] 1 SCR 87 at 110 [Cognos], the Court had listed five elements of negligent misrepresentation, with the existence of a special relationship between the representor and representee being the first of them. Precedents that give checklists are strongly attractive, and thus the special relationship keeps getting referred to. One example of this blurring is Premakumaran v Canada, 2006 FCA 213, [2007] 2 FCR 191, in which the Court referred extensively to both Hercules and Cognos, but basically applied the special relationship test. The Court said at para 17 that negligent misstatement was an existing category of case, so a full Anns analysis was unnecessary.

67 In the one psychiatric injury case the Court has recently adjudicated, Mustapha v Culligan of Canada Ltd, 2008 SCC 27, [2008] 2 SCR 114, the Court handled the psychiatric injury question as a question of remoteness rather than duty. The duty of the water company to take care to keep its product unadulterated was seen to fulfil the duty requirement. The Court below had analyzed the problem as one of duty of care. Because it resolved the duty issue on foreseeability grounds the Court did not need to apply the Anns test, though it did refer to it: Mustapha v Culligan of Canada Ltd (2006), 84 OR (3d) 457 at paras 28, $47(\mathrm{CA})$ [Mustapha $\mathrm{CA}]$.

68 The English courts have made extensive use of proximity analysis in bystander cases: McLoughlin $v$ O'Brian, [1983] 1 AC 410 (HL (Eng)); Alcock v Chief Constable of South Yorkshire Police, [1992] 1 AC 310 (HL (Eng)); White v Chief Constable of South Yorkshire Police, [1999] 2 AC 455 (HL (Eng)); Wv Essex County Council (2000), [2001] 2 AC 592 (HL (Eng)). Canadian courts have struggled with the duty issue, uncertain whether the English proximity analysis carried over intact into Canadian law: Devji v Burnaby (District), 1999 BCCA 599, 180 DLR (4th) 205 at paras 48, 71, 99; Mustapha CA, ibid 


\section{Do We Really NeEd the AnNS TeSt?}

In light of the experience Canadian law has had with the Anns test, we come to the question posed in the title of this article. The title states the question unhelpfully because in one sense we clearly do not need the Anns test. England and Australia, to name two jurisdictions, have a law of negligence without it. The question, to put it more accurately, is whether the Anns test adds value to our law — that is, whether it performs a necessary role and performs it better than the alternatives. To start with whether the role it performs is necessary, the answer for all practical purposes is yes. We do need a reasonably articulable method for determining whether a duty of care exists. It has been suggested recently that the whole concept of duty of care could be scrapped in favour of asking explicitly the distinct questions encapsulated in it. ${ }^{69}$ However, the concept is probably too entrenched in our thinking to be dispensed with.

Does the Anns test, as applied in Canada, provide a better method for determining whether a duty of care exists than the alternatives? Judged by its performance over the last 30 years, it holds up reasonably well against its major foreign counterparts. It is at least as good as the "fair, just, and reasonable" approach taken in the English cases ${ }^{70}$ and probably better than the indeterminate "salient features" line taken in Australia. ${ }^{71}$ Nevertheless, is it the best we can do?

The main benefit promised by the Anns test is to steer judges into making duty of care decisions according to a consistent framework rather than just proceeding ad hoc. However, when one looks closely at the pattern of decisions, the methodological consistency starts to look more like a uniform façade stuck on a row of different buildings. The test actually operates very differently depending on what the duty problem is.

In public authority cases, the test is basically a means of setting the boundary between public and private law duties. Especially after Cooper, this is done mainly under the rubric of proximity in the first stage of the test, where the courts assess the compatibility of a private law duty of care with the defendant's public mandate. Generally, where the public officials are dealing with the plaintiff's interests directly, proximity can be found. ${ }^{72}$ Where they are regulating a branch of activity generally, proximity usually is not found. ${ }^{73}$ To a lesser extent these cases depend on the second stage of the test, in deciding whether the public authority's liability would be too open-ended (the indeterminacy problem) or whether

at para 28. Louise Bélanger-Hardy sees merit in using Anns to decide negligence cases involving psychiatric injury, at least in comparison to the present confused state of the law: "Nervous Shock, Nervous Courts: the Anns/Kamloops Test to the Rescue?" (1999) 37:3 Alta L Rev 553. She draws support from Hercules' use of Anns to deal with negligent misrepresentation (ibid at 579-80). Donal "Deconstructing the Duty of Care" (2013) 129:4 Law Q Rev 559. That the concept of duty is useful, but should be reconceived as a unified concept, is argued by David Howarth, "Many Duties of Care - Or A Duty of Care? Notes from the Underground"'(2006) 26:3 Oxford J Leg Stud 449.

See supra note 13 .

See supra notes 14-15.

See e.g., Carhoun \& Sons Enterprises Ltd v Canada, 2015 BCCA 163, 76 BCLR (5th) 300, especially at para 97.

See e.g., Williams v Canada (Attorney General), 2009 ONCA 378, 95 OR (3d) 401 (management of epidemic). One case where proximity was held arguably present, although the public body was dealing with a set of importers, is Paradis Honey Ltd v Canada (Minister of Agriculture and Agri-Food), 2015 FCA 89, 382 DLR (4th) 720, leave to appeal to SCC refused, 36471 (29 October 2015). Compare Los Angeles Salad Co v Canadian Food Inspection Agency, 2013 BCCA 34, 358 DLR (4th) 581. 
attaching liability in negligence to a particular decision would assert too much judicial control over the executive arm of government (the policy/operational problem). ${ }^{74}$

In novel private actor duty of care cases, the test is for all practical purposes a means of assessing the merits of incremental extensions of the law of negligence in cases of nonphysical harm (pure economic loss or possibly psychiatric injury) or nonfeasance. Very occasionally, it is used to carve out a policy-based exception to a duty of care that generally exists (as in Dobson).$^{75}$ In these cases the proximity part of the (post-Cooper) test usually does the heavy lifting. It is true that indeterminate liability, which is often a major factor for not imposing a duty of care, was always treated as a second stage factor before Cooper, since all policy considerations were relegated to the second stage. After Cooper, however, indeterminacy could be brought in at either stage. A mass of potential claimants who could make just the same claim as the plaintiff, which is one form of indeterminacy, ${ }^{76}$ can just as easily be seen as showing a lack of proximity between defendant and plaintiff. A complete inability by the defendant to gauge its potential liability to the plaintiff, which is another form of indeterminacy, ${ }^{77}$ can also be seen either as showing a lack of proximity or as a second stage policy question.

According to Hercules, in negligent misrepresentation cases, the Anns test operates not to evaluate an asserted new category of the law of negligence, but to decide on whether the representor should be taken to have assumed a duty of care on the particular facts of the case. The Court in Hercules did not introduce the Anns test into this setting in order to change the course of decisions, or even the factors a court should consider, but just to bring the duty issue in negligent misstatement under the same umbrella as that in other parts of the law of negligence. It did so, but (as the continuing reference to special relationship shows) the assimilation gave no practical advantage. ${ }^{78}$ If Anns were to be used in psychiatric injury cases, the results, as suggested earlier, might well be similar. It can be added that, in this use of Anns, the boundary between the first and second stage of the test is especially hazy. Where the assessment is so case-specific, should this defendant be under a duty of care to this plaintiff under these circumstances, the distinction between proximity (the policy factors having to do with the relationship) and residual policy (the policy factors having to do with the system generally) is hard to discern.

An example of the latter is Imperial Tobacco, supra note 1.

Dobson, supra note 1. Compare Hubley v Hubley Estate, 2011 PECA 19, 315 Nfld \& PEIR 79 (a widow claimed that her deceased husband had owed her a duty of care not to cause his own death, which resulted in her suffering economic loss. This was held to be a novel category of duty of care that failed for want of proximity). Another example of policy negating an otherwise plausible duty of care is Correia $v$ Canac Kitchens, 2008 ONCA 506, 91 OR (3d) 353 (a claim that an employer negligently initiated an investigation into whether the plaintiff employee was a thief and a drug trafficker was held to fail for want of a duty of care, since it would be against policy to discourage employers from investigating potential criminal activity by their staff).

As in Bow Valley, supra note 1.

As in Hercules, supra note 1.

An argument that the Anns approach does have advantages compared with the traditional approach to negligent misstatement is made in Andrew Barker, "Divining an Approach to the Duty of Care: The New Zealand Court of Appeal and Claims for Negligent Misstatement" (2001) 10:1 Otago L Rev 91. It does, of course, as soon as the claim falls outside the strict parameters of negligent misstatement, which is a claim based on loss caused by relying on the misstatement. Thus harm caused by words, other than through the plaintiff's reliance on them, can be seen as better accommodated within the Anns test: Robert Hollyman, "Hercules Managements and the Duty of Care in Negligent Misstatement: How Dispensable is Reliance?" (2001) 34:2 UBC L Rev 515. 
Even if the uniformity offered by the Anns test is more apparent than real in these respects, it can be argued that it nevertheless still performs a valuable service. It structures the duty analysis, albeit in a wide range of disparate settings, in a particular way. This argument is essentially that the merit of the test resides in its two stages. The first and second limbs articulate the vital distinction between denying liability because there is no prima facie duty of care (the asserted duty fails at the first stage of the test) and denying liability on overriding policy grounds (there is a prima facie duty but liability is denied on policy grounds).

A notable proponent of this view is Andrew Robertson. He suggests that it is right, and important, to distinguish between interpersonal justice factors (what foreseeability and proximity, rightly understood, are) and factors based on systemic impacts (such as justiciability, community welfare, the effect on a class of potential defendants, inefficient allocation of risk, and adverse behavioural effects). ${ }^{79}$ The reason the distinction matters is that courts should put the onus on the plaintiff to satisfy them that, as a matter of justice between the parties, a duty of care should be found. On the other hand, the onus should be on the defendant to show that this prima facie duty should be trumped by larger systemic concerns. So understood and applied, the Anns two-stage test "provides a remarkably effective mechanism for mediating between the interests of justice and the interests of community welfare." 80

There is a lot to be said for this way of understanding the Anns test, but at the risk of failing to do justice to its merits, two qualifications may be suggested. One is that the distinction between factors going to interpersonal justice and those going to the broader system works best where the question is the extension of negligence to a new category of case involving the liability of a private actor. Interpersonal justice does not really fit justice as between citizen and public authority, because the issue of justice as between the two is inextricable from the systemic factor of the nature of the authority's statutory mandate. Nor does the distinction between interpersonal justice (or relationship-related) factors and general welfare (or residual) policy factors hold up well when Anns is used in a case-specific fashion, as it has been in the context of negligent misstatement. Deciding whether to impose a duty of care in a class of cases can be said to involve systemic pros and cons. The same cannot be said of deciding whether there should be a duty of care in an individual case, or even a class of cases that is highly fact-specific. Systemic issues must have been resolved at a more general level. This happened, in effect, when the courts decided that negligent misrepresentation can be a tort in appropriate circumstances. It is the presence or absence of the appropriate circumstances that is assessed in the individual case.

The other suggested qualification is that the ability of the two-stage structure (even where it works best) to deliver its analytical payoff depends mainly on whether it can give effective guidance to the courts. The point of the two-stage method is to indicate to courts how to

79 Andrew Robertson, "Justice, Community Welfare and the Duty of Care" (2011) 127:3 Law Q Rev 370 [Robertson, "Justice"]. See also Robertson, "Policy," supra note 2. One attempt to define the systemic factors is found in Stephen D Sugarman, "A New Approach to Tort Doctrine: Taking the Best From the Civil Law and Common Law of Canada" in Stéphane Beaulac, Stephen GA Pitel \& Jennifer L Schulz, eds, The Joy of Torts (Markham: LexisNexis, 2003) 375 at 388-89. See also the analysis of the twostage test in JA Smillie, "The Foundation of the Duty of Care in Negligence" (1989) 15:3 \& 4 Monash UL Rev 302.

80 Robertson, "Justice," ibid at 395. 
weigh the two categories of factors against each other. The reversal of the onus as between stage one and stage two is the key to this guidance. However, the onus is essentially one of persuasion not of proof. ${ }^{81}$ Because of this, the stage one conclusion that there is a prima facie duty, is inevitably going to be weighed against the stage two policy factors on very elastic scales. There is therefore room for some skepticism about how much guidance, in practice, the two-stage structure gives as to the metrics by which the courts are to balance the first stage factors against the second stage ones.

\section{Conclusion: Should We KeEP the ANNS TeSt?}

For the reasons suggested above, the advantages of the Anns test as a means of approaching duty of care questions are hard to pin down. In response it can be said that it has no particular disadvantages. There is no doubt that policy has to be integrated into the analysis of duty questions, and the case can be made that the Anns test has been as good a means as any for doing that. It is certainly true that, looking at the Supreme Court's decisions, the actual results are by and large supportable. ${ }^{82}$ I would argue, however, that the test does have two disadvantages in the way it is currently applied.

First, as discussed above, it treats duty questions that are very unalike - public authority liability, private actor liability in novel types of case, negligent misstatement — as if they were basically alike. The concept of novel categories works quite differently between these types of duty issues, and the proximity analysis plays a different role in each. To elide these differences by using a purportedly universal analytical template can only create confusion — not debilitating, but not insignificant either.

Second, even where it works best, in deciding whether to extend liability to new types of harm or new types of duties of affirmative action, it can distract courts by inviting them to set off down the Anns road when a more direct route would be better. A good example is Martel Building, in which the Supreme Court held that the federal Crown, as tenant of the plaintiff's building, could not be liable in tort for negligence in its conduct of the ultimately fruitless negotiations to renew the lease. ${ }^{83}$ The Court deployed Anns and held that, although there was a prima facie duty of care owed by the Crown as tenant to the landlord (this was pre-Cooper), a slew of second-stage policy reasons militated against the recognition of the duty. I would argue that the recourse to Anns was unnecessary because there was a short answer to the plaintiff's claim. Since, as a matter of contract law the tenant was under no

81 It is true that the Court in Childs, supra note 1 at para 13, described the onus on residual (i.e. second stage) policy considerations as an "evidentiary burden," but considerations like the risk of indeterminate liability are really not susceptible to proof by evidence, and the courts do not refer to evidence when applying them. The one second stage consideration that is to some extent evidence-based is the distinction between policy and operational decisions of public authorities, since that distinction is drawn based on evidence as to how and why the authority made the decision in question.

82 I would make an exception for Winnipeg Condo, supra note 1, which I would argue created a tort remedy for latent structural defects in acquired property when it was not needed - and, moreover, basically rescued the property owner from having overpaid for the property because the owner did not factor in the risk of such defects. The law of contract already offers the builders, intermediate sellers, and the ultimate owner a much better system for allocating the risks of defects. Martel, supra note 1. 
obligation to negotiate for a renewal at all, it logically could not be liable in negligence for negotiating unsuccessfully. ${ }^{84}$

Three decades of the Supreme Court's repeated approval of the Anns test, even if it has revised the meaning of the test during that time, make it unlikely that the test will be retired anytime soon. I would suggest that, at least, it should be applied with a greater recognition of its limitations particularly because it operates differently in public authority, private actor, and negligent misstatement cases. I think it would also be worth considering whether it should be used only in the private actor duty cases. Public authority duty cases could then be dealt with squarely on the basis of the relevant policies, which are linked to constitutional and administrative law, without the distraction of the two-stage test. Negligent misstatement could be handled - and actually, despite Hercules, is often handled — using properly developed criteria for assessing individual cases, as under the rubric of special relationship, without the need to pay lip service to a two-stage analysis.

The most radical step would be to declare that the Anns test has fulfilled its historic destiny in Canadian law, which has been to legitimize and make explicit the role of policy in deciding duty of care questions. In view of its limitations, it is worth thinking, now or later, about whether its continuing value to our law is outweighed by its disadvantages and whether we would be better off in the decades to come if, with gratitude for its long service, we laid it aside. 
This page is blank - do not strip it in 